\title{
MEMANDANG MUKJIZAT PENYEMBUHAN DALAM TERANG IMAN
}

\author{
Elvin A tmaja Hidayat \\ U niversitas Katolik Parahyangan, Bandung
}

\begin{abstract}
A bstract:
Since the beginning of its existence, Christianity has been often associated with "paranormal healing". Jesus himself, with His disciples, often performed healing as a sign of the presence of the Kingdom of God in the world, even in person who was healed. The widespread interest and belief in miracles of physical and spiritual healing, in essence, does not degrade the noble dignity of the Christian faith. On the contrary, this increasingly popular phenomenon can help the Church maintain its existence and re-articulate its rel evance for the faithful. More recently, the number of these "miracle healing" groups, both outside and within the Church, is increasingly widespread and likely to obscure faith. Because of this urgency, the Church should seek ways to investigate as deeply as possible the nature of this healing, especially in order to prevent people from being astray.
\end{abstract}

Keywords: Miracle, Healing, Pray, Faith, Reconciliation, Love, Magisterium.

\begin{abstract}
A bstrak:
Sejak awal keberadaannya, agama Kristen sering dikaitkan dengan "penyembuhan paranormal". Yesus sendiri, dengan murid-murid-N ya, sering melakukan penyembuhan sebagai tanda kehadiran Kerajaan Allah di dunia, banyak orang yang disembuhkan. Pada hakekatnya, kepentingan dan keyakinan yang meluas tentang mukjizat penyembuhan fisik dan spiritual, tidak menurunkan martabat mulia iman Kristen. Sebaliknya, fenomena yang semakin populer ini dapat membantu Gereja mempertahankan eksistensinya dan mengartikulasikan relevansinya bagi umat beriman. Baru-baru ini, banyak yang mengalami "mukjizat penyembuhan", baik di luar maupun di dalam Gereja, semakin meluas dan cenderung mengaburkan iman. Atas situasi ini, Gereja harus mencari cara untuk menyelidiki lebih mendalam hakekat mukjizat penyembuhan, terutama untuk mencegah orang dari kesesatan.
\end{abstract}

Kata-kata Kunci: Mukjizat, Penyembuhan, Doa, Iman,Rekonsiliasi, Cinta, Magisterium 


\section{Pengantar: Mukjizat sebagai Kerinduan Umat Manusia}

Dalam konteks kehidupan beriman-sepanjang sejarah Gereja, banyak peristiwa atau fenomena di luar nalar yang sering kita dengar atau baca dari orang lain, atau bahkan kita saksikan sendiri. Sebut saja beberapa yang paling populer di antaranya: stigmata, levitasi, bilokasi, bahasa roh, eksorsisme, penampakan-penampakan kudus, jenazah para Kudus yang tak membusuk (incorruptible saints), hosti dan anggur ter-transubstansiasi yang sungguh berubah menjadi Tubuh dan Darah Kristus, dan Iain-lain. Artikel ini berikhtiar membahas salah satu fenomena 'supranatural' tersebut, yakni: “Mukjizat Penyembuhan melalui Kuasa Doa”. Mungkin, sebagian orang berpendapat bahwa bahasan ini kurang menarik dan kurang esensial dalam hidup menggereja, yang penting bagi mereka adalah "aksi" atau tindakan ad extra bagi sesama. Bisa jadi, ada juga yang meremehkan topik ini dengan mengatakan bahwa "mukjizat terbesar telah dialami manusia setiap saat, yakni nafas kehidupan. Untuk apa lagi berbicara soal mukjizat yang lain?" Terlepas dari berbagai ‘nada sumbang' seputar mukjizat, Gereja tak dapat menutup mata, bahwa setiap fenomena ajaib, khususnya "mukjizat penyembuhan" ini, menjadi salah satu basis terkuat bertumbuhnya iman akan ke-Mahakuasa-an Allah. Bahkan, bisa jadi, sebagaisalah satu alasan kuat mengapa orang tetap bertahan dalam Katolisisme. ${ }^{1}$ Faktanya, kesehatan atau kesembuhan memang merupakan komoditas "berdaya jual tinggi"; yang dinanti, didamba, bahkan dicari-cari banyak orang di seluruh dunia, termasuk umat beriman Kristiani. Mungkin, inilah salah satu alasan mengapa Gerakan Pembaruan Karismatik Katolik, yang rutin menyelenggarakan doa-doa bertajuk "penyembuhan", bisabertumbuh subur di kalangan Gereja.

Sekitar tahun 2009, saya berkesempatan menghadiri suatu acara Kebangunan Rohani Katolik bertajuk "penyembuhan" yang diadakan di JITEC, Mangga Dua Square, Jakarta Utara. Kala itu, auditorium berkapasitas kurang lebih enamribu lima ratus orang itu penuh. Bahkan, umat membludak sampai di luar aula. Masih jelas pula dalam ingatan saya, bahwa dalam perhelatan akbar tersebut, sejumlah besar orang yang menderita berbagai sakit-penyakit maju ke depan altar, didoakan oleh para romo dan tim doa, lalu "mendadak sembuh". Seorang anak kecil, misalnya, mencampakkan begitu saja alat bantu berjalan (tongkat kruk) yang semula digunakannya untuk menopang tubuhnya. Sang anak berwajah polos itu, kemudian kembali menuju tempat duduknya sambil berlari girang. Sontak, ribuan umat, termasuk saya, berdiri dan bertepuk

1 Gereja Katolik mengajarkan bahwa “mukjizat-mukjizat memperkuat iman kepada Yesus, yang melaksanakan pekerjaan Bapa-Nya". Lih. Katekismus G ereja Katolik, No. 548. 
tangan penuh keterpukauan. Fenomena ini menunjukkan bahwa umat Kristiani (tidak semua yang hadir beragama Katolik) mempunyai kerinduan amat besar akan mukjizat, terutama "mukjizat penyembuhan". Mukjizat semacam ini, dan banyak lagi lainnya, memang selalu menarik untuk disaksikan dan didiskusikan.

\section{Pandangan Kristiani atas Mukjizat Penyembuhan melalui D oa}

A khir-akhir ini, berbagai alternatif penyembuhan semakin merebak sebagai jawaban atas kerinduan utopis manusia untuk memperoleh hidup nyaman dan bahagia, bebas dari sakit-penyakit, dan dari berbagai penderitaan. Beberapa jenis penyembuhan alternatif tersebut saya sebutkan di sini: reiki, kundalini, yoga, akupuntur, dan yang paling kuno dan terkesan angker, melalui dukun-dukun (magic). ${ }^{2}$ Penyembuhanpenyembuhan ajaib yang dipropagandakan secara agresif oleh gerakangerakan modern, seperti Christian Science, juga perlu 'diwaspadai'. ${ }^{3}$ Berhadapan dengan semua gejala yang bertebaran tak terbendung di depan mata ini, Gereja ditantang untuk merefleksikan secara mendalam hakikat penyembuhan 'supranatural' tersebut. Jangan sampai, umat menjadi bingung, resah, dan terganggu imannya karena adanya hal-hal yang mengaburkan kebenaran iman Kristiani dalam praktik-praktik semacam itu. Dalam kerangka inilah, artikel ini berusaha memperdalam wawasan perihal mukjizat penyembuhan; dengan menyajikan pandangan biblis, teologis, dan magisterium Gereja sebagai ajaran resmi.

\subsection{Perspektif Biblis: Perjanjian Lama (PL) dan Perjanjian Baru (PB)}

Secara etimologis, "mukjizat" dalam PL berasal dari kata Ibrani Ôth, yang berarti "tanda", dan digunakan untuk menunjuk wabah-wabah

2 Beberapa referensi berikut bisa membantu telaah atas metode-metode penyembuhan tersebut. Tentang "reiki" dan "kundalini", baca Hendra Puntoro, Reiki \& Kundalini: Tinjauan Kritis Sudut P andang I man Kristiani, Bandung, Yayasan A ndipani, 2002. Tentang “yoga”, baca Waheguru S. Khal sa, The M iracle of $\mathrm{H}$ ealing $\mathrm{H}$ ands: The $\mathrm{C}$ omplete Guide to A ncient $\mathrm{Y}$ ogic $\mathrm{H}$ ealing and M assage Technique, Beverly Hills, Rishi Knot Publisher, 1997.Tentang metode penyembuhan alternatif dengan "sihir" atau "mantra", sebagaimana dimaksud oleh yang terakhir disebutkan ini, lihat salah satu reportase dari Meridith Kohut, "Obat Putus Asa" dalam $N$ ational G eographic Indonesia, Juli 2017, 82-87.

3 Kelompok Christian Science ini, secara agresif mempropagandakan ajaran-ajaran mengenai ilmu pengetahuan dan kesehatan, salah satu caranya, dengan menerbitkan secara rutin majalah BENTARA. Majalah ini terbit tiga bulan sekali dan diterjemahkan dalam Sembilan bahasa, termasuk Bahasa Indonesia. Dalam beberapa hal fundamental, aliran ini bertentangan dengan kekristenan. Misalnya: membedakan antara Kristus dengan Yesus, menyangkal keilahian Yesus Kristus, Roh Kudus atau Roh Penghibur adalah Christian Science, kesia-siaan pengorbanan Yesus, Surga berada dalam bumi, dsb. Lih. https:// pormadi.wordpress.com/2009/03/16/beberapa-aliran-sesat-dalam-kekristenan/ D iakses pada 11/11/ 2017, 15:27 WIB. 
(tulah) atas Mesir (Keluaran 7:3). Sementara itu, dalam PB, biasa digunakan tiga kata Yunani: 1) semeion (dalam Injil Sinoptik, berarti "tanda" dalam artian agak negatif: untuk melegitimasikan. Dalam Injil Yohanes, menunjuk pada "mukjizat agung": salib dan kebangkitan Kristus.), 2) dunamis (yaitu "kuasa yang mengagumkan; suatu tindakan Allah"), dan 3) ergon (yang berarti "kuasa").4

Terkait urgensinya, Reginald $\mathrm{H}$. Fuller berpendapat bahwa dua peristiwa pokok yang terdapat di dalam keseluruhan Alkitab, baik dalam Perjanjian Lama (PL) maupun Perjanjian Baru (PB) adalah peristiwa "mukjizat". Dua peristiwa pokok yang dimaksud ialah "Peristiwa Keluaran" (dalam PL) dan "Peristiwa Kristus" (dalam PB). Kedua mukjizat terbesar ini, dalam Alkitab, selalu didahului oleh mukjizatmukjizat yang lebih kecil, yang menaruh perhatian kepada arti mukjizat besar yang sebenarnya ini, sekaligus mempersiapkannya. Sebelum "Peristiwa Keluaran", misalnya, ada peristiwa tulah atas Mesir sebagai mukjizat-mukjizat kecil. Pola yang sama terjadi untuk mengawali "Peristiwa Kristus" (wafat dan kebangkitan-Nya), yakni penyembuhanpenyembuhan dan pengusiran roh jahat.. Dalam pandangan Fuller ini, mukjizat penyembuhan dianggap tak istimewa ("hanya peristiwa kecil") jika dibandingkan dengan Kristus sendiri beserta penebusan-Nya. Tetapi, keduanya memang tidak bisa dibandingkan, karena secara hakiki bersifat komplementer dan tak terpisahkan. Artinya, penyembuhanpenyembuhan itu sendiri dilakukan Yesus dalam rangka pewartaan Kerajaan Allah dan penebusan-N ya pula.

Dalam konteks PL, sakit-penyakit dan penderitaan manusia ditempatkan dalam konteks religius. Penyakit, terutama dipandang sebagai kelemahan dan kesalahan manusia, atau "hukuman dari Tuhan atas dosa manusia". ${ }^{6}$ Dalam konteks PB, penyakit dimaknai secara baru, dalam kaitannya dengan mukjizat-mukjizat penyembuhan yang dilakukan Yesus; yakni, sebagai tanda kedatangan Kerajaan Allah sekaligus karya penebusan-Nya bagi manusia. Mukjizat dalam PB mengandung nuansa yang berbeda, yakni penegasan bahwa hal-hal ajaib tersebut sungguh merupakan perbuatan Roh atau tangan Allah sendiri,

4 Bdk. Reginald H. Fuller, M enafsirkan M ukjizat, Yogyakarta, Kanisius, 1991, 15-17.

5 Reginald H. Fuller, ibid., 10. Pendapat Fuller yang mengasosiasikan "mukjizat" dengan "peristiwa atau pribadi Kristus sendiri" dapat disepadankan dengan ajaran Gereja, yang memandang Kristus sebagai keselamatan, rahmat dan penyembuhan bagi manusia yang sedang susah. Ia bukan sekadar pewarta kabar yang menggembirakan, melainkan Dia sendirilah Kabar Gembira itu. Lih. Konferensi Waligereja Indonesia (KWI), Iman Katolik, Buku Informasi dan Referensi, 1996, 266.

6 Uraian lebih lengkap dalam Elvin A tmaja H., "Iman di Tengah Penderitaan: Suatu Inspirasi Teologis-Biblis Kristiani", dalam Jurnal M E LIN TA S Volume 32, No. 3, Desember 2016, 290293 dan 307 (Endnotes 13). 
bukan sekadar perbuatan manusia biasa. ${ }^{7}$ Penggunaan "kata pasif" dalam Matius 11:5-6 (“...orang kusta ditahirkan, orang mati dibangkitkan..."), misalnya, menurut Fuller, menunjukkan bahwa mukjizat penyembuhan bukan pekerjaan Yesus sendiri sebagai manusia pembuat mukjizat, melainkan Allah sendirilah yang mengerjakannya melalui Yesus. ${ }^{8}$ Selain hal-hal penting di atas, PB juga menggarisbawahi dua hal penting bagi terjadinya penyembuhan melalui doa, yakni adanya "iman" dan "rekonsiliasi".

Berdasarkan eksplorasi atas sejumlah ayat PB, dapat ditarik tiga simpulan mengenai penyembuhan melalui kuasa doa yang dikerjakan oleh Yesus:

1) Pentingnya iman untuk memperoleh kesembuhan.

Dalam pelayanan publik-Nya yang dikisahkan dalam PB, Yesus hampir selalu didatangi ol eh orang-orang sakit, baik secara langsung maupun melalui teman dan saudara-saudara mereka. Mereka mendambakan penyembuhan "ajaib" di kala segala pengobatan medis-manusiawi sudah tak dapat lagi menyembuhkan penyakit mereka. Tuhan Yesus selalu menerima permohonan mereka, namun beberapa kali menyayangkan kekurangpercayaan mereka, misalnya, Ia bersabda: "Jika Engkau dapat! Segala sesuatu mungkin bagi orang yang mempunyai kepercayaan (iman)" (M rk. 9:23). Yesus pun berjanji, "apa juga yang kamu minta dalam nama-Ku, Aku akan melakukannya, supaya Bapa dipermuliakan di dalam Anak..." (Yoh. 14:13-14). Dalam kesempatan lain, Yesus kembali bersabda, "Jikalau kamu tinggal di dalam A ku..., mintalah apa saja..., dan kamu akan menerimanya" (Yoh. 15:7). Yesus menuntut supaya orang percaya bahwa Dia sanggup menyembuhkan, misalnya ketika Ia menyembuhkan anak Yairus (M rk. 5:36-42) dan ketika la menyembuhkan dua orang buta (M at. 9:28). Bahkan, ketika la menyembuhkan anak yang dirasuki setan, Yesus menuntut supaya ayahnya percaya akan kemampuan atau kuasa-N ya (M rk. 9:23). Matius mencatat bahwa Yesus tidak dapat berbuat banyak mujizat di Nazaret karena mereka tidak percaya (M at. 13:58). A yat-ayat dalam PB ini, menunjukkan bahwa "iman" kepada-Nya menjadi salah satu persyaratan bagi terkabulnya permohonan manusia, termasuk penyembuhan atau kesehatan.

2) Yesus menyembuhkan seseorang menurut kehendak- $\mathrm{N}$ ya sendiri, namun manusia bisa memohonkannya.

7 Reginald H. Fuller, op. cit., 38.

8 Reginald H. Fuller, ibid., 39. 
Gagasan kedua ini eksplisit, misalnya, dalam peristiwa Yesus menyembuhkan orang lumpuh di kolam Betesda (Yoh. 5:6-9); ketika la membebaskan orang yang kerasukan roh jahat (M rk. 1:2325; M atius 8:28-32); dan ketika la membangkitkan anak muda di Nain (Luk. 7:12-15). Tuhan tahu apa yang terbaik bagi manusia (R m. 8:28), bahkan sebelum dimintakan kepadanya. kepercayaan kepada Tuhan untuk menyembuhkan memang perlu, tetapi manusia tidak dapat memaksa Tuhan. Ada kalanya orang tak langsung disembuhkan, karena terkadang, "Tuhan menghajar orang yang dikasihi-Nya, dan la menyesah orang yang diakui-N ya sebagai anak." (I brani 12:6). Dengan kata lain, kekuatan penyembuhan bukan tergantung pada manusia (pribadi pendoanya), melainkan semata-mata dari Allah. Penyembuhan merupakan hak prerogatif Allah. Akan tetapi, manusia juga bisa membuat penyembuhan itu menjadi mungkin dengan doa-doa yang penuh iman (Mrk. 7:24-30, tentang "Perempuan Siro-Fenisia yang Percaya").

3) Pentingnya "rekonsiliasi" sebagai prasyarat lain penyembuhan. ${ }^{9}$

Dalam PB, Yesus juga menekankan pentingnya aspek "rekonsiliasi" (memperbaiki relasi yang rusak dengan diri sendiri dan sesama karena dosa-dosa) untuk memperoleh penyembuhan atau terkabulnya doa. Hal ini, misalnya, tampak dalam Matius 5:24, “tinggalkanlah persembahanmu di depan mezbah itu dan pergilah berdamai dahulu dengan saudaramu, Ialu kembali utuk mempersembahkan persembahanmu itu". Yesus, sepertinya, mau mengatakan bahwa Allah hanya akan mengabulkan doa-doa seseorang, apabila ia telah menyel esaikan segala permasalahan (konflik)-nya dengan sesama. Tekanan terhadap aspek rekonsiliasi juga termaktub dalam perkataan Yesus ketika menyembuhkan seorang lumpuh, "Hai anak-Ku, dosamu sudah diampuni" (Mrk. 2:5). Yesus tidak mengatakan "penyakitmu sudah disembuhkan", namun "dosamu". Tampak adanya korelasi erat antara dosa (tindakan yang berdampak spiritual sekaligus sosial) dengan kesehatan manusia. Banyak kesaksian beredar mengenai orang-orang yang berangsur-angsur pulih dari berbagai macam sakitpenyakit, setelah ia mencoba mengampuni sesama, menerima Sakramen Pengampunan Dosa, dan melakukan aktivitas positif lainnya. Rekonsiliasi yang saya maksud di sini bermakna seluas-

9 Tentang "Rekonsiliasi", lihat juga RobertJ. Schreiter, The M inistry of Reconciliation, Spirituality \& Strategies, New York, Orbis Books, 1998, dan A. Widyahadi Seputra, dkk. (Ed.), Rekonsiliasi: M enciptakan H idup D amai dan Sejahtera, Jakarta, Komisi PSE/ APP-KAJ, LDD-KAJ, PSE-KWI, LPPS-KWI, 2001. 
luasnya; tidak hanya berarti berdamai dengan Allah, sesama, dan diri sendiri, tetapi juga dengan keadaan atau situasi yang tidak dapat diubahnya. ${ }^{10}$

Selain dalam kisah-kisah Yesus, ajaran mengenai mukjizat penyembuhan melalui kuasa doa dalam PB juga dapat ditemukan dalam surat-surat Rasul Paulus. Ayat 1K orintus 12:28-30, misalnya, berbunyi demikian:

“... Allah telah menetapkan beberapa orang dalam Jemaat: pertama sebagai rasul, kedua sebagai nabi, ketiga sebagai pengajar. Selanjutnya, mereka yang mendapat karunia untuk mengadakan mujizat, untuk menyembuhkan, melayani, memimpin, dan untuk berkata-kata dalam bahasa roh. Adakah mereka semua rasul, atau nabi, atau pengajar? Adakah mereka semua mendapat karunia untuk mengadakan mujizat, atau untuk menyembuhkan, atau untuk berkata-kata dalam bahasa roh, atau untuk menafsirkan bahasa roh?"

Dari kutipan biblis di atas, ditambah beberapa ayat lainnya dari surat-surat Paulus, dapat ditarik tujuh gagasan Iain mengenai mukjizat penyembuhan. Ketujuh gagasan di bawah ini akan memperkaya tiga gagasan yang telah dipaparkan sebelumnya:

1) Roh Kudus menetapkan (memilih) orang-orang tertentu untuk menerima karunia-karunia tertentu, sebagaimana yang dikehendaki-Nya. Jadi, Roh Kudus-lah yang berdaulat penuh.

2) Karunia-karunia itu "didistribusikan". Jadi, tiada seorangpun yang memonopoli semua karunia. Bukan suatu keharusan pula bahwa salah satu karunia harus dimiliki oleh setiap orang. Intinya, semua mesti bekerjasama sesuai kapasitas masingmasing.

3) Karunia-karunia itu diberikan Roh Kudus untuk kepentingan bersama, untuk pertumbuhan dan pembangunan Jemaat (lih. juga 1Kor. 12:7 dan 14:5, 12); bukan untuk kesenangan atau kebanggaan personal. Dalam hal kesembuhan ilahi, terhadap orang di luar K ristus, ia berfungsi sebagai tanda bahwa berita Injil itu benar dan Yesus adalah benar-benar Tuhan dan Juruselamat. Terhadap Jemaat, ia berguna untuk membangun iman dan kerohanian mereka.

4) Mukjizat penyembuhan merupakan kehendak (berasal dari AlIah) semata. Rasul Paulus, misalnya, memiliki karunia untuk menyembuhkan yang begitu besar sehingga saputangan atau kain yang pernah dipakainya saja, bila diletakkan atas orang

10 Terkait penerimaan diri ini, baca James M. McMahon, Radical Self A cceptance: The Spiritual Birth of the Human Person, N ew York, Crossroad Publishing Company, 1999. 
sakit, maka orang itu kemudian sembuh (Kis. 19:11-12). Akan tetapi, Paulus pernah mengalami ketidakberdayaan dalam menyembuhkan rekan-rekannya (1Tim. 5:23; 2 Tim. 4:20). Artinya, kalau Allah tak berkenan menyembuhkan, penyembuhan oleh seorang manusia sehebat apapun tak akan terjadi.

5) Ada-tidaknya suatu karunia pada seseorang tidak mengindikasikan ataupun menjamin taraf kerohaniannya. Maka, tidak ada alasan untuk berbangga ataupun bersedih. Bahkan, jemaat Korintus yang berlimpah-limpah dengan karunia Roh Kudus masih ditegur oleh Rasul Paulus sebagai "manusia duniawi, yang belum dewasa dalam Kristus" (1Kor. 3:1).

6) Ada karunia-karunia yang menarik perhatian, spektakuler, ada yang tidak. Namun semua karunia itu sama pentingnya (bdk. 1 Kor. 12:21-27).

7) Tidak pernah disebutkan bahwa Roh Kudus memberikan karunia-karunia itu hanya pada zaman Rasul-rasul saja. Sampai saat ini, Allah tetap berkarya secara luar biasa dalam dunia. ${ }^{11}$

\subsection{Perspektif Teologis: Pandangan beberapa Teolog}

Kebanyakan teolog memiliki alur pemikiran sepaham dalam hal posisi Yesus Kristus sebagai sentral dari peristiwa-peristiwa mukjizat. Artinya, bahasan mengenai mukjizat penyembuhan dan berbagai mukjizat lainnya sama sekali tidak bisa terlepas dari konteks Yesus. Refleksi Schillebeeckx atas mukjizat, misalnya, bertolak dari sosok Yesus sebagai "miracle worker", yang melalui-Nya, orang dapat melihat kemuliaan Tuhan. Keempat Injil menunjukkan klimaks kemuliaan Yesus itu dalam "crucifixion" (penyaliban). ${ }^{12}$ Dari refleksinya atas Yesus, "mukjizat" baru kemudian ditafsirkan sebagai "tanda-tanda" (signs) yang membuat para murid dan orang banyak menjadi percaya kepada Yesus, sang (pembuat) mukjizat tersebut. Schillebeeckx mengutip Yohanes 1:50 dan Yohanes 20:29, tentang kisah keraguan Thomas, untuk mempertegas pandangannya bahwa "mukjizat merupakan tanda yang menuntun orang pada iman". ${ }^{13}$

Terkait sentralitas pribadi Yesus dalam peristiwa mukjizat, $\mathrm{H}$ ans Küng mengatakan bahwa "Miracles alone prove nothing". ${ }^{14} \mathrm{Küng}$

11 Keyakinanini diserukanoleh Sr. Briege McKenna, OSC dan Henry Libersat, dalam buku mereka:M ukjizat-mukjizat di Zaman M odern: Tuhan M asih M elakukan Karya-karya A gung-N ya, Yogyakarta, Kanisius, 1995.

12 Edward Schillebeeckx, Christ: The Christian Experience in the M odern World, London: SCM Press, 1980, 373.

13 Bdk. Edward Schillebeeckx, ibid., 376. 
menilai, historisitas mukjizat (kebenaran faktualnya dalam PB) bukanlah pertanyaan penting bagi iman Kristiani. Pertanyaan krusial yang lebih mendesak untuk dijawab, ialah, mengenai siapa Kristus: apa yang manusia pikirkan tentang Dia (melalui mukjizat-mukjizat yang telah dikerjakan-Nya)? Menurutnya, kunci untuk memahami mukjizat dalam PB bukanlah soal perlawanan hukum alam, bukan pula tentang pemerintahan universal Allah di atas muka bumi, melainkan "Jesus himself". Terkait peran dari sang tokoh kunci ini, Küng melihat bahwa Yesus sama sekali tidak mempropagandakan ajaran pribadi atau diri-Nya sendiri melalui seluruh mukjizat yang diselenggarakannya. Fokus Yesus ialah semata-mata keselamatan manusia. ${ }^{15}$

Küng melangkah lebih jauh, dengan berpendapat bahwa setiap mukjizat yang dilakukan Yesusjuga merevelasikan siapa diri-N ya. Sebagai contoh, penyembuhan seorang buta menandakan identitas Yesus sebagai "Cahaya Dunia"; penghidupan kembali orang mati menandakan diriNya sebagai "Kebangkitan dan Hidup", dsb. ${ }^{16}$ Tuntutan akhir dari mukjizat-mukjizat, masih menurut Küng, bukanlah iman terhadap kebenaran mukjizat itu sendiri, melainkan iman kepada Y esus yang merevelasikan diri melalui mukjizat tersebut. Melalui semua mukjizat yang dilakukan-Nya, Yesus mau menegaskan bahwa Kerajaan Allah tak hanya diwartakan bagi orang-orang kaya dan terkemuka, melainkan juga bagi orang-orang lemah, sakit, tua, cacat, dan yang termarjinalkan oleh dunia. Dalam konteks ini, Yesus bukan hanya berperan sebagai preacher dan adviser, melainkan juga menjadi healer dan helper ${ }^{17}$ Sebagai catatan akhir dari refleksinya atas mukjizat, Küng mengatakan bahwa mukjizatmukjizat Yesus, pada hakikatnya memberi kesan mengenai pejumpaan dengan kekuatan ilahi, yakni: "Kerajaan Allah", yang tidak sekadar menebus dan membebaskan tubuh (dari sakit dan kerapuhan), melainkan juga membawa transformasi dan penyempurnaan dunia. ${ }^{18}$

Dalam pandangan Walter Kasper, "mukjizat" juga dipandang sebagai aspek unik dan misterius (yang tak terpisah dari sosok dan peristiwa) Yesus. ${ }^{19}$ Ia melawan pendapat Goethe yang menyebut mukjizat sebagai "faith's favourite children", dengan mengatakan bahwa sekarang ini, mukjizat telah menjadi "faith problem-children". ${ }^{20}$ Mukjizat menjadi

14 Hans Küng, On Being a Christian, New York, Doubleday \& Company, 1976, 236.

15 Hans Küng, ibid.

16 Hans Küng, ibid., 237.

17 Hans Küng, ibid.

18 Hans Küng, ibid. 238.

19 Bdk. Walter Kasper, Jesus the Christ, New York, Paulist Press, 1976, 89. Dalam kurung dari saya.

20 Walter Kasper, ibid. 
masalah iman karena mulai dipertanyakan historisitasnya. Akan tetapi, sama seperti Küng, Kasper terlihat lebih mementingkan hal lain daripada validitas aspek kesejarahan mukjizat. Ia berhasil menunjukkan tiga argumen bahwa mukjizat dalam Kitab Suci sungguh historis. Namun, Kasper lebih tertarik untuk menekankan aspek kedatangan Kerajaan Allah melalui mukjizat-mukjizat tersebut, yang juga berarti permulaaan kehancuran kerajaan setan. ${ }^{21}$ Kasper merumuskan tiga arti positif mukjizat Yesus: 1) sebagai pemenuhan Perjanjian Lama, 2) Perwujudan kekuatan Allah dalam kesepian, keterasingan, ambiguitas, dan skandal manusia, dan 3) sebagai jal an pemuridan. Kasper juga menggagas koneksi dua arah antara iman dan mukjizat. Ia menulis, "Tujuan mukjizatmukjizat ialah membimbing manusia pada iman. Sebaliknya,untuk melihat dan mengenali mukjizat sebagaimana adanya mukjizat tersebut, yakni sebagai karya Allah, mengandaikan adanya iman." 22

A gak berbeda dari para teolog di atas, Hans Urs von Balthasar menggambarkan doa sebagai kontemplasi, yang berlandaskan pada ketiga Pribadi Trinitas. Tekanannya tidak hanya pada Yesus. ${ }^{23}$ Sayangnya, dalam karyanya mengenai "doa", Balthasar tidak secara eksplisit membahas mengenai mukjizat melalui kuasa doa tersebut.

Sementara itu, Tom Jacobs membahas doa penyembuhan secara eksplisit dalam "Teologi Doa"-nya. Ia memandang bahwa doa penyembuhan memuat banyak dimensi; yang pasti, hal itu bersifat positif. Ia menulis, "Doa penyembuhan dapat merupakan suatu dukungan rohani positif, yang tidak hanya bersifat psikologis, kultural, dan sosial, tetapi juga spiritual-sejauh mendukung iman orang sakit". ${ }^{24}$ Bernhard Häring, teolog moral terkemuka, mengungkapkan pengalaman semacam ini. Ia menceritakan pengalamannya sembuh dari kanker paru-paru secara ajaib, sepuluh tahun lalu. Ketika dokter menyatakan bahwa kankernya telah hilang tanpa bekas, orang-orang bertanya, "siapa orang kudus yang menjadi panutannya, sehingga mukjizat ini bisa terjadi". Häring mengatakan bahwa ia sama sekali tidak berdoa dengan perantaraan para kudus manapun. Ia menjawab, "Saya hanya berdoa semoga Allah membantu saya mengakhiri hari-hari akhir hidup saya dengan baik dan pasrah kepada kehendak Allah". ${ }^{25}$ Doa-doa penyembuhan yang dimohonkan orang-orang untuknya, sekurang-kurangnya,

21 Walter Kasper, ibid., 95.

22 Walter Kasper, ibid., 97-98.

23 Hans Urs von Balthasar, Prayer, N ew York, Sheed \& Ward, 1961, 11-55.

24 Tom Jacobs, Teologi D oa, Yogyakarta, Kanisius, 2004, 126. Tampak bahwa “aspek iman” juga menjadi tekanan.

25 Bernhard Häring, D oa N afas H idupku, Jakarta, Obor, 2004, 19. 
menyembuhkan secara mental-spiritual. Ia menjadi siap menerima risiko terburuk dari penyakit yang dideritanya. Kesembuhan fisik yang diterima setelahnya, hanyalah implikasi dari penyembuhan mental tersebut.

Terkait efektivitas doa penyembuhan, teolog John $\mathrm{H}$. Wright menegaskan bahwa doa pujian dan syukur (praise and thanksgivingprayer) merupakan doa yang paling efektif. Wright berasumsi bahwa pujian dan ungkapan terima kasih akan membuat orang lain merasa senang dan nyaman, sehingga apa yang diminta kemudian daripadanya akan lebih mudah dikabulkan. Walaupun tak selalu benar, bisa jadi, Allah juga merespons demikian. ${ }^{26}$ Dalam Persekutuan Doa Karismatik Katolik (PDKK), pujian dan syukur, yang juga disertai penyembahan kepada Allah, merupakan irama doa yang khas. Mereka biasanya lebih familiar dengan istilah "praise and worship". Dengan demikian, pernyataan Wright mampu menjelaskan mengapa mukjizat-mukjizat penyembuhan terjadi lebih masif dalam persekutuan-persekutuan doa karismatik. A kan tetapi, melalui telaahnya atas beberapa ayat Alkitab, Wright menegaskan bahwa pujian kepada Allah sama sekali tidak membuat Allah merasa jadi lebih penting. ${ }^{27}$ Singkatnya, pujian dan penyembahan manusia tidak menambah kemuliaan Allah, melainkan lebih untuk keselamatan manusia itu sendiri. Kalaupun doa memohon kesembuhan atau meminta apapundikabulkan-bukan karena Allah ingin membalas puji-pujian dan penyembahan manusia, tapi semata-mata karena la ingin melakukanNya berdasarkan cinta. A kan tetapi, bagi Fuller, kerahiman juga bukan sekadar alasan bagi terjadinya suatu mukjizat. Mukjizat dipandang oleh teolog biblis ini sebagai "tindakan langsung dari kerahiman Ilah itu sendiri". ${ }^{28}$

Pandangan-pandangan para teolog di atas tidak selalu mewakili pandangan resmi Gereja. Oleh karena itu, bagian selanjutnya mengenai perspektif Gereja (magisterium), berikhtiar memurnikan atau meluruskan berbagai pandangan yang telah dipaparkan di atas.

26 John H. Wright, A Theology of Christian Prayer, New York,Pueblo Publishing Company, 1979, 56. Dalam buku ini, Wright juga memaparkan dua jenis doa lainnya selain "praise and thanksgiving", yakni "petition" (seruan atau permohonan) dan "intercession" (doa melalui perantaraan orang lain). Lih. halaman 67-85. Sementara itu, Jordan A umann menglasifikasi doa dalam lebih banyak kategori sesuai tingkatannya, yakni V ocal Prayer, M editation, A ffective Prayer, Prayer of Simplicity, C ontemplative Prayer, Prayer of Q uiet, Prayer of U nion, Prayer of Conforming U nion, dan Prayer of T ransforming U nion. Lih. Jordan Aumann, Spiritual Theology, New York, Continuum, 2006, Bab 12, 316-357.

27 Bdk. John H. Wright, ibid., 59-60.

28 Reginald H. Fuller, op. cit., 13. 


\section{Memaknai 'Penyembuhan Ajaib' berdasarkan Magisterium Gereja}

Gereja Katolik, melalui Kongregasi untuk Ajaran Iman, secara resmi mengafirmasi kebenaran adanya mukjizat penyembuhan melalui kuasa doa. Dalam dokumen yang diterbitkan pada tahun 2000, Gereja memaparkan secara kronologis fenomena mukjizat penyembuhan tersebut mulai sejak zaman PB, dalam tradisi Gereja, sampai pada konteks zaman sekarang. ${ }^{29}$ Dokumen ini mencatat bahwa sepanjang perjalanan sejarah Gereja, telah ada banyak pekerja mukjizat suci yang melakukan penyembuhan menakjubkan. Banyak pula kesaksian mengenai penyembuhan yang dikaitkan dengan tempat doa (tempat suci, yang menyimpan relikwi para kudus, dan lain-lain.). Fenomena penyembuhan tersebut diakui sebagai "penambah popularitas peziarahan" ke tempattempat suci tertentu, misalnya ke tempat St. Martinus Tours, Katedral St. Jacobus-Compostela, dan Lourdes. ${ }^{30}$

Dalam dokumen ini, "penyembuhan" dimaknai secara khas, yakni sebagai persatuan dengan Kristus:

"Kemenangan Kristus atas sakit-penyakit, dan atas kesengsaraan manusia dalam bentuk lainnya, tidak terjadi hanya dengan menghilangkannya melalui mukjizat penyembuhan, namun melalui penderitaan-Nya yang teguh, suka rela, dan tanpa dosa di kayu salib, Kristus telah membuka kesempatan bagi semua orang untuk mempersatukan diri mereka masing-masing ke dalam kesengsaraan Tuhan kita." ${ }^{31}$

Hal lain yang juga ditegaskan oleh dokumen ini, ialah, pembedaan antara kebaktian doa untuk penyembuhan, yang berkaitan dengan "karisma penyembuhan", dengan yang tidak dikaitkan dengannya. Kebaktian terkait "karisma penyembuhan" merujuk pada adanya campur tangan seorang atau beberapa orang tertentu yang menentukan kemujaraban doa penyembuhan. Bila tidak ada kaitannya dengan karisma penyembuhan, Gereja menyatakan sungguh layak dan pantaslah untuk merayakan ibadat liturgis, misalnya Misa untuk Orang Sakit (pro infirmis).32 Terkait doa-doa penyembuhan liturgis, Gereja mengingatkan bahwa perayaan ini sah sejauh makna aslinya tidak diubah. Misalnya, dalam Adorasi Sakramen Mahakudus, janganlah keinginan memperoleh penyembuhan dijadikan yang utama sehingga berpotensi menghilangkan

29 Kongregasi untuk Ajaran Iman (terj.: M. Purwatmo), Instruksi mengenai D oa Penyembuhan, Jakarta, Departemen Dokumentasi dan Penerangan Konferensi Waligereja Indonesia, 2009, No. 3-5, 13-19.

30 Tentang Lourdes, baca: Stephen Grosso, Kisah-kisah Kesaksian Iman dari Lourdes, Yogyakarta, Kanisius, 1999.

31 Instruksi mengenai Doa Penyembuhan, no. 1, par. 7.

32 Instruksi mengenai D oa Penyembuhan, no. 5, par. 3. 
tujuan khasnya, yaitu membawa umat merasakan kehadiran Kristus dalam Ekaristi. ${ }^{33}$ Pada bagian akhir, dokumen ini menggarisbawahi tiga hal: 1) "karisma penyembuhan" tak dapat dikenakan pada golongan tertentu (1Korintus 12), 2) pembagian karunia dikerjakan oleh Roh yang satu dan sama (1Kor. 12:11), 3) harus diyakini adanya putusan bebas Roh Kudus dalam memilih orang-orang tertentu sebagai penerima karisma khusus penyembuhan; untuk menunjukkan kuasa rahmat Kristus yang bangkit. 34

Dokumen Gerejani lainnya layak disebutkan pula dalam bagian ini, misalnya D ominum et Vivificantem (1986) yang merefleksikan secara mendalam peran Roh Kudus dalam kehidupan Gereja dan dunia. Ensiklik yang terbit empat belas tahun sebelum diterbitkannya Instruksi mengenai D oa Penyembuhan ini, telah terlebih dahulu menyatakan dukungannya terhadap gerakan-gerakan rohani, yang memberikan tempat utama bagi doa dan mencari dalam doa suatu pembaruan bagi kerohanian mereka. Gereja menilai gerakan semacam ini sebagai tanda yang berarti dan yang memberikan penghiburan. Sebab, melalui gerakan-gerakan inilah, muncul suatu sumbangan real bagi pembaruan kehidupan doa di kalangan umat beriman umumnya, bagi pengenalan lebih dalam akan Roh kudus, dan bagi bertumbuhnya kesucian dalam hati manusia. Dokumen ini juga menegaskan bahwa "zaman kita yang sulit ini (memang) membutuhkan suatu doa khusus". 35

Pada tahun 2003, Kongregasi untuk Kebu dayaan, bekerjasama dengan Kongregasi untuk Dialog A ntaragama-Vatikan, menerbitkan dokumen "Jesus Christ, the Bearer of the Water of Life, A Christian Reflection on the $\mathrm{N}$ ew A ge". Terkait mukjizat penyembuhan, dokumen ini memaparkan berbagai fenomena pengobatan alternatif yang merebak di zaman modern, yang mendapat popularitas amat mencolok karena klaimnya akan kemampuan penyembuhan holistik. ${ }^{36}$ Dokumen ini "menentang" keyakinan umum dari penyembuhan-penyembuhan alternatif semacam itu, yang mengajarkan prinsip bahwa seseorang dapat menciptakan sendiri realitasnya. Dalam artian tertentu, manusia dipandang sebagai "allah" pula. Situasi cacat berat atau menderita sakit yang tak tersembuhkan, umumnya dianggap oleh pengobatan-pengobatan al ternatif, sebagai

33 Bdk. Instruksi mengenai Doa Penyembuhan, no. 5, par. 4.

34 Instruksi mengenai Doa Penyembuhan, ibid.

35 Paus Yohanes Paulus II (terj.: J. Hadiwikarta), D ominum et V ivificantem, Jakarta: Departemen Dokumentasi dan Penerangan Konferensi Waligereja Indonesia, 1992, No. 65, par. 3.

36 Pontifical Council for Culture \& Pontifical Council for Interreligious Dialogue (terj.: Widyo Soewondo), Y esus K ristus Pembawa A ir H idup: Sebuah R efleksi K ristiani tentang N ew A ge, Jakarta, Departemen Dokumentasi dan Penerangan Konferensi Waligereja Indonesia, 2008, No. 2.2.3. 
kelemahan manusia dalam menghayati hidup mereka. Manusia sendirilah yang mendatangkan kemalangan itu bagi dirinya. Dalam konsep semacam ini, terjadi semacam penipuan dan perendahan martabat manusia. Gereja menyatakan penolakan terhadap konsep semacam itu dengan mengajarkan bahwa keterbatasan-keterbatasan manusia adalah sebuah fakta hidup dan menjadi bagian dari keterciptaan manusia. Kematian dan kehilangan, dalam kekristenan, (justru) memberi tantangan dan kesempatan untuk semakin mengimani janji Allah akan kebangkitan badan, dalam kebangkitan Yesus Kristus. ${ }^{37}$

Dokumen ini, terlihat seolah-olah menentang penyembuhanpenyembuhan alternatif ala $\mathrm{N}$ ew A ge, dengan menyuruh manusia menerima sakit-penyakit dan penderitaannya sebagai bagian dari hidup. A kan tetapi, benarkah Gereja seolah mengajarkan bahwa sakit-penyakit dan penderitaan harus diterima manusia begitu saja, alias di hidupi dengan pasif dan pasrah? Rasanya, tidak tepat demikian. Dalam konteks inilah, Katekismus mengajarkan tentang doa: "Perjuangan rohani dari kehidupan baru seorang Kristen tidak bisa dipisahkan dari perjuangan doa". ${ }^{38}$ Katekismus melanjutkan, "Perjuangan doa adalah perjuangan manusia dalam kemenangan (atas) kehidupan". ${ }^{39}$ Katekismus juga mengajarkan bahwa "Doa penyembuhan dapat menjadi saat di mana Tuhan menunjukkan mukjizat dan tanda sehingga orang menjadi percaya (bdk. Luk. 7:22-23), sekaligus menjadi simbol dipulihkannya kembali kesehatan manusia seutuhnya, jiwa dan badan". ${ }^{40}$ Bisa disimpulkan, bahwa dalam kekristenan, "doa" dapat dipandang sebagai alternatif, bahkan salah satu cara terbaik penyembuhan manusia; daripada harus terjebak dalam praktik-praktik penyembuhan alternatif yang berpotensi besar mengaburkan iman dan menuntun manusia menjauh dari Sang Keselamatan.

\section{Mukjizat Dimungkinkan oleh Cinta}

Bagian ini dimaksudkan untuk melengkapi sekaligus menjadi titik temu atas berbagai perspektif yang telah dipaparkan di atas. Sebab, "cinta" atau "kasih" dianggap sentral dalam relasi intrahuman. Cinta merangkul setiap manusia; ia bersifat lintasgenerasi, kultur, dan keyakinan. Berbagai perspektif ilmu menunjukkan bahwa mukjizat penyembuhan tidak hanya terjadi karena adanya semacam proses "trans-

37 Bdk. Yesus Kristus Pembawa Air Hidup: Sebuah Refleksi Kristiani tentang N ew Age, No. 6.1, subjudul ketiga.

38 Katekismus Gereja Katolik, No. 2725.

39 Katekismus Gereja Katolik, No. 2805.

40 Bdk. Katekismus Gereja Katolik, no. 1503. 
fer energi" dari sang pendoa, serta adanya "iman" serta "kedamaian hati (rekonsiliasi)" dari orang yang didoakan, melainkan juga karena adanya "relasionalitas dalam cinta", antara si pendoa dengan yang didoakannya.

Larry Dossey, dengan latar belakang sains-medis yang digelutinya, menegaskan bahwa kekuatan cinta dalam mengubah atau menyembuhkan tubuh sudah terkenal; tak hanya dalam dunia medis-kedokteran, melainkan juga dalam kisah rakyat, akal sehat, bahkan dalam pengalaman sehari-hari. ${ }^{41}$ Dossey menceritakan penelitian David McCleland yang telah membuktikan secara medis, kekuatan cinta dalam membuat tubuh lebih sehat. McCleland memperlihatkan kepada para mahasiswanya di Harvard, film dokumenter tentang Bunda Teresa, yang dengan penuh kasi h sayang melayani orang sakit di Kalkuta. la mengukur kadar immunoglobulin A (IgA) pada air liur mereka sebelum dan sesudah melihat film "penuh cinta" itu. ${ }^{42}$ Alhasil, tingkat-tingkat IgA pada para mahasiswa itu meningkat drastis usai menonton film tersebut. Untuk mencapai efek ini dengan cara lain, McCleland juga menggunakan metode yang berbeda. la tidak menggunakan film lagi, melainkan menyuruh para mahasiswanya mengingat saat-saat ketika mereka merasa paling dicintai atau diperhatikan, juga saat mereka mencintai orang lain. Bertolak dari pengalamannya sendiri, McCleland berhasil menghalau serangan virus selesma dengan teknik ini. Berdasarkan serangkaian percobaannya, McCleland akhirnya menjadi salah satu penganjur peranan cinta dalam penyembuhan modern. Kepada rekan-rekan dokternya, ia merekomendasikan metode-metode pendekatan dengan cinta semacam ini. ${ }^{43}$

Salah seorang ilmuwan dan peneliti terbesar dalam sejarah parapsikologi, F.W.H. Myers, juga menemukan fakta mengejutkan bahwa orang-orang yang bisa berhubungan secara telepatik satu sama lain, ternyata memiliki kedekatan emosional dan penuh cinta. Myers menyimpulkan bahwa cinta, empati, dan belaskasih, entah bagaimana caranya, membuat pikiran mampu mengatasi keterbatasan-keterbatasan tubuh. ${ }^{44}$ Dengan kata lain, berdaya "menyembuhkan".Dapat dikatakan juga, bahwa, "cinta" merupakan entitas yang membentuk suatu ikatan atau resonansi; ia merupakan perekat antara makhluk-makhluk hidup. J.B. Rhine dan Sara Feather, misalnya, menemukan lima puluh empat kasus mengenai hewan-hewan yang bisa "pulang ke rumah" atau menemukan kembali majikannya, bahkan di tempat yang belum pernah

41 Larry Dossey, H ealing W ords, Jakarta, PT Gramedia Pustaka Utama, 1996, 105.

42 "IgA" adalah antibodi dalam tubuh manusia yang giat melawan infeksi-infeksi virus, misal nya, selesma.

43 Larry Dossey, op. cit., 106.

44 Larry Dossey, ibid., 106-107. 
didatangi oleh hewan tersebut. ${ }^{45} \mathrm{Cinta}$ (dan empati) teruji mempengaruhi hubungan antarmakhluk hidup, bahkan dari perspektif teologis, menjadi "jembatan penghubung" antara manusia dengan Allah. ${ }^{46} \mathrm{H}$ ubungan yang amat agung ini memungkinkan terjadinya efek-efek pemulihan dari sakitpenyakit. Dalam perspektif ini pula, menyembuhkan orang lain bisa diartikan sebagai menyembuhkan diri sendiri. Sebab, berkat cinta, pembedaan-pembedaan spasial antara diri dengan "yang dicintai" tak lagi menjadi krusial. Barangkali, inilah sebabnya mengapa doa-doa bagi orang lain, terkadang juga bisa bermanfaat bagi diri kita sendiri. Bagi Fromm, cinta adalah "satu-satunya jawaban yang waras dan memuaskan terhadap masalah eksistensi manusia". ${ }^{47}$

Sementara itu, dalam perspektif Teologis-Kristiani, "cinta” itubahkan diidentifikasi sebagai Allah sendiri. Istilah Latinnya, "Deus Caritas Est", menjadi judul ensiklik pertama Paus Benediktus XVI (terbit 25 Desember 2005). Ungkapan ini mengacu pada surat pertama Yohanes, "Deus caritas est, et, qui manet in caritate, in Deo manet, et Deus in eo manet" (1 Yoh 4: 8). Dalam pernyataan teologis ini, Allah dikenali bukan hanya sebagai sumber cinta kasih, melainkan "Allah adalah kasih" itu sendiri. ${ }^{48}$ Orang yang berada di dalam kasih berarti tinggal di dalam Allah dan Allah di dalam Dia. Pandangan teologis-kristiani ini bisa menjadi salah satu landasan terkuat untuk menjelaskan bagaimana "cinta" mampu menyembuhkan sakit-penyakit. Sebab, cinta adalah (perwujudan dari) Allah Yang Mahakuasa itu sendiri. ${ }^{49}$

\section{Penutup: Berdoalah dengan Tidak Jemu-jemu}

Tulisan ini berikhtiar meneguhkan umat beriman, untuk tetap berdoa dan berharap, meskipun tampaknya tiada harapan lagi. Sebab, seluruh uraian dari topik ke topik, menunjukkan bahwa doa itu berdaya guna; karenaTuhan adalah Mahabaik dan Ia tidak pernah tertidur. Umat beriman juga disadarkan mengenai dahsyatnya kuasa doa, yang bisa "dikirimkan" kepada semua orang yang dicintainya, kapan pun, dan di

45 Kisah-kisah dramatis tersebut dimuat dalam buku mereka yang berjudul Parapsychology Laboratory. Lih. Larry Dossey, ibid., 108.

46 Lih. Elvin A tmaja H., "Belas Kasih: Jembatan Penghubung Manusia dengan Allah", dalam Jurnal FORU M , Vol. 45, No. 1/ 2016, terutama (hlm.) 45-46.

47 Erich Fromm, The A rt of Loving, Jakarta: PT Gramedia Pustaka Utama, 2014, pada kover belakang.

48 Paus Benediktus XVI (terj: Piet Go), D eus Caritas Est, Jakarta, Departemen Dokumentasi dan Penerangan Konferensi Waligereja Indonesia, 2010.

49 Jeanrond membahas pandangan Kristiani mengenai "cinta" secara apik, termasuk konsep "God is Love". Lih. Werner G. Jeanrond, A Theology of Love, London: T\&T Clark, 2010, khususnya (hlm.) 239-259. 
mana pun mereka berada. A kan tetapi, umat beriman juga harus mengingat bahwa doa dan ulah kesalehan tidak selalu manjur menghindarkan manusia dari penderitaan dan sakit-penyakit. Kendatipun demikian, setidaknya, doa-doa tersebut senantiasamampu memberikan kekuatan bagi manusia, untuk menghadapi sakit-penyakit atau penderitaannya-dalam iman.Melalui tulisan ini pula, umat Kristiani, terutama para kaum religius, diingatkan akan apa yang hakiki dalam hidupnya, yakni, bahwa mereka dipanggil untuk pertama-tama menjadi seorang 'pendoa'. Salah satu tujuan penulisan ini, ialah menyadarkan para imam dan kaum religius, bahwa "doa" bukanlah tugas atau kewajiban yang harus dilaksanakan, melainkan bagian tak terpisahkan (integral)dalam kehidupan mereka. Hendaknya, doa menjadi bagaikan nafas kehidupan bagi seorang religius. Akan tetapi, pada dasarnya,setiap umat Kristiani diharap mampu semakin "menghidupi doa", apalagi karena doa-doa terbukti berdaya menyembuhkan.Dengan iman sebesar biji sesawi saja, mukjizat dimungkinkan mengalir "lebih lancar". Dalam artian ini, kita sekalian dituntut untuk menjadi saluran rahmat Allah bagi sesama yang mendambakannya; menjadi "pelaku mukjizat" seperti Yesus. Tetapi, harus diingat bahwa hal terpenting bukanlah mukjizat-mukjizat-nya, melainkan dampak lanjutannya, yakni "mempertemukan" manusia dengan Allah. ${ }^{50}$

Tulisan ini juga hendak mengimbau para penggiat Doa-doa Penyembuhan, agar jangan pernah merasa memiliki kepenuhan rahmat Roh Kudus (merasa angkuh), karena intensitas keberhasilan doa yang terjadi dalam dan melalui pribadi atau kelompok mereka. Sebab, "Roh berembus ke manapun Ia mau!" (Bdk. Yohanes 3:8).Keberhasilannya bergantung pada Allah dan bukan terletak pada kehebatan pribadi manusia. Selain itu, sesuai dengan anjuran Gereja, untuk tujuan apapun, hendaklah kelompok-kelompok doa penyembuhan semacam ini, tidak melakukan peribadatan penuh histeria, bersifat artifisial, sandiwara, ataupun sensasionalisme..$^{51}$ Memang,seringkali, perjumpaan dengan Allah terasa jauh lebih konkret dalam peristiwa mukjizat, yang adikodrati itu. Sebagai catatan akhir, seluruh komponen Gereja, terutama para praktisi doa, kembali diingatkan agar berhati-hati. Sebab, "mukjizat atau tanda-tanda juga bisa menimbulkan skandal" di kalangan umat beriman. Hal semacam ini juga terjadi dalam Matius 11:6, ketika Yesus dianggap

50 Romo Yohanes Indrakusuma, CSE, menegaskan bahwa dalam Misa (Doa-doa) Penyembuhan, sesungguhnya, penyembuhan fisik bukan merupakan tujuan akhir. Ia menekankan bahwa "penyembuhan rohani", yakni pertobatan-sebagai tujuan terpenting. Selain itu, ia juga menegaskan bahwa dirinya sama sekali tidak bisa menyembuhkan; yang bisa menyembuhkan hanya Tuhan sendiri.Maria Etty, dkk., Y ohanes Indrakusuma, 0. Carm, Sang Petapa Sejati, Jakarta, Fidei Press, 2007, 37.

51 Instruksi mengenai D oa Penyembuhan, 5.3. 
melakukan mukjizat dengan kuasa setan..$^{52}$ Maka, umat beriman harus memiliki kepekaan dalam "membedakan Roh". Daya membedakan roh ini juga penting, mengingat maraknya praktik-praktik penyembuhan di luar Gereja, yang nyaris serupa dan mungkin tampak lebih 'menakjubkan'. Hendaknya, umat Katolik bersikap kritis dalam mengikuti perkembangannya atau ketika secara terpaksa harus berpartisipasi dalamnya (mempraktikkannya); jangan sampai tercerabut dari akar kekatolikan. Karena itulah, sekali lagi, umat diajak untuk sungguh memahami secara mendalam iman kekatolikannya dan senantiasa berdoa dengan tidak jemu-jemu (Bdk. Luk. 18:1).

* Elvin A tmaja Hidayat

Biarawan O rdo SalibSuci (O SC);M ahasiswa Pascasarjana/M agister IImu T eologi U niversitas Katolik Parahyangan (U N PA R), Bandung. Email: elvin.atmaja@yahoo.com

\section{BIBLIOG RAFI}

Aumann, Jordan, Spiritual Theology, New York: Continuum, 2006.

Balthasar, Hans Urs von, Prayer, New York: Sheed \& Ward, 1961.

Dossey, Larry, H ealing W ords, Jakarta: PT Gramedia Pustaka Utama, 1996.

Etty, Maria, dkk., Y ohanes Indrakusuma, 0. Carm, Sang Petapa Sejati, Jakarta: Fidei Press, 2007.

Fromm, Erich, The A rt of Loving, Jakarta: PT Gramedia Pustaka Utama, 2014.

Fuller, Reginald H., M enafsirkan M ukjizat, Yogyakarta: Kanisius, 1991.

Grosso, Stephen,Kisah-kisah Kesaksian Iman dari Lourdes, Yogyakarta: Kanisius, 1999.

Häring, Bernhard, D oa N afas H idupku, Jakarta: Obor, 2004.

Hidayat, Elvin Atmaja, “Belas Kasih: Jembatan Penghubung Manusia dengan Allah", dalam Jurnal FO RU M , Vol. 45, No. 1/ 2016.

"Iman di Tengah Penderitaan: Suatu Inspirasi Teologis-Biblis Kristiani", dalam Jurnal M ELINTAS Volume 32, No. 3, Desember 2016.

https://pormadi .w or dpress.com/2009/03/16/beberapa-aliran-sesat-dalamkekristenan/Diakses pada 11/11/2017, 15:27 WIB.

Jacobs, Tom, Teologi D oa, Yogyakarta: Kanisius, 2004.

Jeanrond, Werner G., A Theology of Love, London: T\&T Clark, 2010.

52 Katekismus Gereja Katolik, N o. 548. 
Kasper, Walter, Jesus the Christ, New York: Paulist Press, 1976.

Katekismus Gereja Katolik (terj.: Harry Susanto), Jakarta dan Yogyakarta: Konferensi Waligereja Indonesia dan Kanisius, 2009.

Khalsa, Waheguru S., The M iracle of $\mathrm{H}$ ealing $\mathrm{H}$ ands: The Complete Guide to A ncient Y ogic $\mathrm{H}$ ealing and $\mathrm{M}$ assage Technique, Beverly Hills: Rishi Knot Publisher, 1997.

Konferensi Waligereja Indonesia (KWI), Iman Katolik, Buku Informasi dan Referensi, 1996.

Kongregasi untuk Ajaran Iman (terj.: M. Purwatmo), Instruksi mengenai D oa Penyembuhan, Jakarta: Departemen Dokumentasi dan Penerangan Konferensi Waligereja Indonesia, 2009.

Küng, Hans, On Being a Christian, New York: Doubleday \& Company, 1976.

McKenna, Briege dan Henry Libersat, M ukjizat-mukjizat di Zaman M odern: Tuhan M asih M elakukan Karya-karya A gung- $N$ ya, Yogyakarta: Kanisius, 1995.

McMahon, James M., Radical Self A cceptance: The Spiritual Birth of the Human Person, New York: Crossroad Publishing Company, 1999.

Meridith Kohut, "Obat Putus Asa”, dalam N ational Geographic Indonesia, Juli 2017.

Paus Benediktus XVI (terj.: Piet Go), D eus C aritas Est, Jakarta: Departemen Dokumentasi dan Penerangan Konferensi Waligereja Indonesia, 2010.

Paus Yohanes Paulus II (terj.: J. Hadiwikarta), Dominum et V ivificantem, Jakarta: Departemen Dokumentasi dan Penerangan Konferensi Waligereja Indonesia, 1992.

Pontifical Council for Culture \& Pontifical Council for Interreligious Dialogue (terj.: Widyo Soewondo), Y esus Kristus Pembawa A ir H idup: Sebuah R efleksi Kristiani tentang N ew A ge, Jakarta: Departemen Dokumentasi dan Penerangan Konferensi Waligereja Indonesia, 2008.

Puntoro, Hendra, Reiki \& Kundalini: Tinjauan Kritis Sudut Pandang Iman Kristiani, Bandung: Yayasan Andipani, 2002.

Schillebeeckx, Edward, Christ: The Christian Experience in the M odern W orld, London: SCM Press, 1980.

Schreiter, Robert J., The M inistry of Reconciliation, Spirituality \& Strategies, N ew York: Orbis Books, 1998.

Seputra, A. Widyahadi, dkk. (Ed.), Rekonsiliasi: M enciptakan H idup D amai dan Sejahtera, Jakarta: Komisi PSE/ APP-KAJ, LDD-KAJ, PSE-KWI, LPPS-KWI, 2001.

Wright, John H.,A Theology of Christian Prayer, New York: Pueblo Publishing Company, 1979. 